\title{
Beyond the English Box: Constructing and Communicating Knowledge Through Translingual Practices in the Higher Education Classroom
}

\author{
英語授課之外的可能：透過跨語實踐建構與傳遞知識 \\ Sin-Yi Chang ${ }^{1}$
}

Received: 17 July 2018 / Revised: 28 October 2018 / Accepted: 2 November 2018 / Published online: 27 November 2018

(C) The Author(s) 2018

\begin{abstract}
As part of the growing trend of internationalization in higher education, new forms of linguistic practices are recently emerging in diverse contexts. However, such practices are often obscured by English medium instruction (EMI) policies, neglecting the role of other languages, semiotic resources, and modalities in the construction and communication of knowledge. Building on an expanded framework of language policy, in this study I take a "trans-" approach to reconceptualize the "E" in EMI. Specifically, the participants of this study include 18 university lecturers from a range of disciplinary backgrounds. Data was collected over a 6-month period through classroom observations and semistructured interviews. The findings show that translingual practices were not uncommon for a range of epistemological, pedagogical, and social purposes, but at the same time significantly constrained by monolingual ideologies that permeate the policy process. To open up translanguaging spaces in the higher education classroom, the study suggests to move current EMI policies from an English-only focus toward multilingual and translingual awareness. Instead of determining the language of instruction a priori, it is more important to focus on ways to become more linguistically aware and ecologically oriented, acknowledging the process of meaning-making as situated, holistic, and embodied.
\end{abstract}

Sin-Yi Chang

syc39@cam.ac.uk

1 Faculty of Education, University of Cambridge, 184 Hills Rd, Cambridge CB2 8PQ, England 
摘要

因應全球化的趨勢, 英語授課在高等教育國際化的過程中扮演著核心的角色。然而, 主 張「全英語」的論述往往忽略了其他語言、符號、和媒介在建構與傳遞知識上的重要 性。透過語言政策的分析, 此研究嘗試以跨語實践的理論探討英語授課一詞中的「英 語」如何重新定義。此研究的參與者包含十八位不同學科領域的大學教師, 研究方法 涵蓋課室觀察與教師訪談, 資料收集過程為期六個月。研究結果顯示, 跨語實踐並不罕 見, 且在知識的建構上、教學上、和師生的互動上有著不同的意義。即便如此, 過度強 調英語的政策往往是單語主義思想背後的無形推手, 使得跨語實踐的發展空間受到極大 限制。此研究提倡以「多語」和「跨語」的理念取代「全英語」的論述。與其由上而 下規範課室語言, 不如回歸知識建構的本身, 針對不同學科領域的需求與屬性進行教學 。

Keywords English medium instruction · Language policy · Translingual practices · Translanguaging $\cdot$ Internationalization in higher education

關鍵詞 英語授課·語言政策·跨語實践·高等教育國際化

\section{Introduction}

With the increasing trend of internationalization in higher education, new forms of linguistic practices are recently emerging in diverse contexts, as manifested in the promotion of English medium instruction (EMI) for the teaching of different subjects in many non-Anglophone countries $[13,14,55]$. While the growing phenomenon of EMI has received much excitement and enthusiasm on the policy level, the philosophies behind its promotion are often constructed on monolingual instructional principles that restrict the use of other languages in the higher education classroom [15, 18, 42]. Under such influences, English tends to be uncritically accepted as the most desirable medium of instruction, neglecting the role of other languages, semiotic resources, and modalities in the process of constructing and communicating knowledge.

In East Asia, the rising status of English in academia has attracted much research attention in recent years $[20,31,33]$. As a typical case in this region, Taiwan has seen a sharp increase of EMI courses and programs in the past decade as a way to attract international students, and also "to improve the English proficiency of the local students through an increasingly internationalized environment" [24, p. 13]. While there are no explicit national policies dictating classroom linguistic choices, ${ }^{1}$ many universities in Taiwan have established institutional policies to encourage the use of English as the language of instruction, with a high percentage of the universities defining the "E" as "English only" ${ }^{2}$ " $[11,62]$. Although attitudes towards EMI have mostly been positive, there are growing concerns regarding its detrimental effects on content learning and student well-being, in addition to other social issues of equality and access [8, 9, 24, 64, 65]. As EMI movements around the world have often outpaced sufficient research and

\footnotetext{
${ }^{1}$ The push for EMI on the national level is more implicit and indirect, mostly through a combination of funding and branding mechanisms driven by the Ministry of Education (MOE), the Higher Education Evaluation and Accreditation Council of Taiwan (HEEACT), and the Foundation of International Cooperation in Higher Education in Taiwan (FICHET).

2 全英語, or “all English” when translated literally.
} 
theorization $[13,15,18]$, there is a need to examine the phenomenon of EMI with new perspectives of language and learning.

Following this line of thinking, in this study I adopt a "trans-" approach to respond to current calls for reconceptualizing the "E" in EMI $[13,32]$. By "trans-," I refer to the act of crossing borders and boundaries, acknowledging fluidity and flexibility between linguistic structures, systems, and other modalities [21, 40]. Specifically, I combine the "trans-" approach with Spolsky's [60] theory of language policy to explore how translanguaging spaces may be enabled or constrained in the higher education classroom. The significance of this study can be highlighted on three levels: first, I demonstrate the different roles of translanguaging in EMI classroom contexts; second, I draw attention to the forces that influence classroom linguistic decisions; and third, by looking into the intersection of language management, language ideology, and language practice, I offer some tentative suggestions to move current EMI policies from an English-only focus toward multilingual and translingual awareness.

\section{Literature Review and Conceptual Framework}

The literature review centers on what it means to take a "trans-" perspective in teaching. I start from discussing the "trans-" turn in recent language studies, and then move on to explain how this approach, when combined with Spolsky's [60] theory, opens up a space to examine EMI policies from the bottom-up. The literature review closes with a set of research questions that drive this study.

\section{The "Trans-" Turn: Developing a New Theory of Language Practice}

To provide a fuller description and interpretation of linguistic practices in the twentyfirst century, ${ }^{3}$ a number of scholars are working towards the goal of developing a new theory of language that goes beyond structuralist orientations [6, 19, 41, 48]. While it is still too early to arrive at a conceptual agreement, the field of applied linguistics seems to be undergoing a "trans-" turn in several ways [21, 46].

Crossing Linguistic Borders The "trans-" turn implies a shift from seeing language as a static and bounded entity to a fluid and dynamic practice. By positioning language as socially and politically "constructed, maintained, and regulated" [48, p. 286], the emphasis is placed on language as a process instead of language as a product $[5,37$, 50]. In other words, language is viewed as a result of languaging, or the activity of tapping into one's entire linguistic repertoire "to gain knowledge, to make sense, to articulate one's thought and to communicate about using language" [40, p. 2].

Crossing Communicative Borders Motivated by the language ecology metaphor $[12,23]$, adopting a "trans-" approach also means to overcome the "lingua bias"

\footnotetext{
${ }^{3}$ Translingual practices are not unique to the twenty-first century, but enhanced today by the emergence of global economies, international communication, increased transnational mobility, technological advancement, and other forces of globalization [5, 19].
} 
in communication and acknowledge the multimodal nature of multilingual encounters [19, 41]. The modes, with their different affordances and constraints inherited or sedimented over time, are resources for constructing and conveying information [34]. These may include a wide range of physical and social tools, such as artifacts, signs, numbers, graphs, and gestures, for the construction and communication of knowledge. Language is only part of a larger set of semiotic possibilities implicated in the process of meaning-making.

Crossing Disciplinary Borders Reconceptualizing language also has transdisciplinary consequences. Specifically, the "trans-" phenomenon can be analyzed through different theoretical foundations. Some scholars take a psycholinguistic standpoint, emphasizing the role of human agency in communication $[19,41]$. From this perspective, speakers are believed to possess "translanguaging instincts" - the ability to adopt different modes for different communicative purposes, selectively choosing lexical and structural features depending on the context and interlocutor. On the contrary, scholars in the sociolinguistic camp view meaning-making as assembled in situ, describing cognition as distributed, emergent, and embodied [5, 6, 53]. As such, features that have previously been relegated to the spatiotemporal context (e.g., politics, culture, society) are also considered agentive and performative, not just to compensate for the inadequacy of language.

Crossing Social Borders In spite of the differences that have emerged from theorybuilding, scholars tend to agree that the "trans-" turn provides opportunities to challenge existing power structures [21, 37]. In particular, to translanguage is to create "a social space for the multilingual language user by bringing together different dimensions of their personal history, experience and environment, their attitude, belief and ideology" [40, p. 2]. The process is transformative, fostering a sense of criticality and creativity in home, school, and everyday practice [19, 41].

To summarize, taking a "trans-" approach not only means to move between semiotic boundaries, but also to go beyond them [40,41]. In this study, I use the term translingual practice to cover an array of meaning-making activities in the higher education classroom. These activities may include deliberately alternating languages of input and output, using different visual modes for constructing knowledge, raising students' metalinguistic awareness, and building on their multilingual repertoire $[6,12,23,44$, 49]. While the translingual practices discussed in existing research are primarily focused on bilingual education programs in primary or secondary school settings, in this study I move on to examine the changing linguistic realities in the higher education context. Specifically, the aim is to explore how the idea of translanguaging interacts with the increasing role of English in academia $[15,37,46]$. In the next section, I turn to Spolsky's [60] theory of language policy that opens up a space to reconceptualize the "E" in EMI.

\section{Spolsky's Theory: Challenging Monolingual Policies from the Bottom-up}

In this study I examine how the "trans-" approach might find a way to transform EMI through Spolsky's [60] theory of language policy. In response to the macro- and micro-distinction of analysis that has constrained the explanatory power of existing policy research [26, 29, 54], Spolsky's theory was established as "a systematic 
attempt to gather usable data on language policies at all levels" [p. $4 \& 5$ ]. This ecological orientation foregrounds a more dynamic, multilayered, and socially aware understanding of language policy, which goes in line with the new wave of language policy research that seeks to unpack policy in more mobile, fluid, and contextual ways $[13,22,28,51]$.

More specifically, Spolsky's [60] conceptualization of language policy comprises language ideology and language practice in addition to language management. The inclusion of ideology and practice marks an important breakthrough from early language policy studies that see policy as a technocratic, top-down way of management $[17,54]$. Drawing on Hymes' [27] ethnography of speaking, Spolsky defines practice as "the habitual pattern of selecting among the varieties that make up its linguistic repertoire" [p. 5]. By ideology, he refers to the system of ideas assigned to various aspects of language structure and use. The expanded conceptualization offers an opportunity to investigate translingual practice as "appropriation," showing how policy on the ground may differ from policy as conceived authoritatively [38, 39]. As such, Spolsky's theory is also democratic in nature, allowing policy to move away from being perceived as an oppressive tool to a constructive one that allows room for negotiation and participation in the policy process [58].

Building on this line of thinking, in this study I examine the phenomenon of EMI by exploring the interaction between the policies that seek to determine the language of instruction (language management), the process of teaching in the higher education classroom (language practice), and the system of ideas that mediate in between (language ideology). In particular, I position university lecturers at the center of analysis instead of the end point of the policy chain. By doing so, the relationship between policy and practice becomes a two-way activity: while sociopolitical forces of internationalization may influence the way how EMI policies unfold, the lecturers may also negotiate, appropriate, and recontextualize them according to different classroom priorities and demands [59,61].

Driven by these considerations, this study asks: How are translingual practices manifested in higher education EMI contexts? In what ways are these practices enabled and constrained? To address these research questions, in the next section, I move on to explain the research design of this study.

\section{Research Design}

The research at hand is framed as a case study to examine how EMI policies at a specific university were interpreted and translated into practice through a "trans-" approach. More precisely, the case is not the university itself, but the institutional policy that promotes EMI. The case is one instance among many other institutional policies in Taiwan that seek to influence classroom linguistic decisions.

\section{The Case}

In particular, the university where I collected data launched its official EMI policy in 2012. The policy defines the "E" in EMI as "English only," mandating that English should be used for every pedagogical activity in classes labeled as EMI. In other words, 
not only is English the language of instruction, but also the language of the teaching material, the language for discussion, and the language for assessment. The university currently has $10 \%$ of its study body categorized as international. ${ }^{4}$

The EMI policy operates in the form of a bonus scheme, offering incentives to encourage lecturers to switch their medium of instruction to English. The incentives include reduced teaching hours and the opportunity to hire teaching assistants. Lecturers who receive the incentives are required to attend EMI workshops annually. Aside from the workshops, lecturers can also seek further professional development abroad. To ensure that the "English only" policy is thoroughly implemented, the university sends administrators to check on the EMI classes every now and then. If student evaluation for a particular course is below expectation, the lecturer will be prohibited to run EMI courses for one academic year.

\section{Selection of Participants}

The participants of this study included 18 university lecturers across a range of disciplinary backgrounds. Lecturers who offered EMI courses at the undergraduate level in the academic year of 2017/2018 were first identified from the university course selection website, and then approached through e-mail or contact visits. The equivalence of sampling was maintained by making demographic features of the lecturers as similar as possible in terms of their levels of appointment, qualifications, and years of teaching. All of the lectures are native speakers of Chinese and have English as their second or third language. At the outset of the data collection process, informed consent was obtained from the research institution and all the participants. Furthermore, issues of confidentiality and anonymity were maintained by using pseudonyms and member validation techniques.

\section{Data Collection Methods}

As part of the broader critical turn in the social sciences, research on language policy and planning has seen a methodological shift from a positivist, quantitative, problemsolving nature, to a more ethnographic, mixed-methods, and bottom-up approach in the late twentieth century [26, 29, 51]. Following this new wave of language policy research, in this study, I adopted classroom observations and semistructured interviews as data collection methods. All observations and interviews were audio-recorded, which amounts to approximately $60 \mathrm{~h}$ of audio data and field notes gathered over a 6-month period.

To examine the practice aspect of EMI policies, 18 EMI courses were selected for observation, with each set of observation being $2 \mathrm{~h}$ long. Attention was placed on three areas: (1) what languages, semiotic resources, and modalities were used; (2) to what extent they were used; and (3) when, how, and why they were used. The classroom observations were important as they offered insights into specific ways in which local policy actors "appropriate, conform to, skillfully navigate, ignore, or openly contest language-in-education policy prescriptions" [45, p. 94].

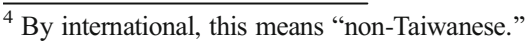


Following the observations, semistructured interviews were carried out with the EMI lecturers to explore how they ideologically react and respond to the institutional EMI policy. Because ideology mediates between policy and practice $[35,63]$, the interviews consisted of two parts ${ }^{5}$ : the first part focused on the lecturers' decision-making during instruction (based on the classroom observations), while the second part examined how the lecturers made sense of the growing use of EMI through an in-depth, phenomenological model of interviewing [57]. One to two interviews were arranged with each lecturer depending on the time needed to cover the main areas of inquiry. The interviews were primarily conducted in Mandarin Chinese, each lasting 60-80 min.

\section{Data Analysis}

The data collected from the classroom observations and interviews were transcribed, ${ }^{6}$ translated, and analyzed through nexus analysis. Building on recent developments in discourse analysis, nexus analysis is a holistic, dynamic, and situated approach emerging from the ethnographic sociolinguistic tradition $[13,30,56]$. When applied to language policy research, it "draws attention to relationships among speakers, languages, policies, and social contexts at varying dimensions of social organization" [25, p. 7].

Specifically, the unit of analysis in this study is a nexus of practice. As the focus is on how lecturers translate and interpret EMI policies "on the ground," the procedure of analysis starts from where translingual practices occur, and then builds out from there to include a range of discourses that respond to such practices [56]. As practice is nested in scales of time and space, different resources and the context in which the practice takes place are kept as part of the analysis $[3,5,6]$. In other words, this means to move the local and the immediate to a broader scope of surveillance, taking into account how policy and practice interpenetrate each other in subtle and fluid ways [7]. For example, in the process of scale-jumping, certain norms or expectations may be explicitly or implicitly indexed in momentary instances of interaction as a way to resist or reproduce power.

Using the microscope as an analogy, Hult [25] describes nexus analysis as zooming "in and out of the different discursive contexts" [p. 9]. By unveiling the interaction between agency and authority, nexus analysis provides a powerful lens to address the dynamics of translingual practice in the higher education setting. In this sense, nexus analysis can be viewed as a "trans-" approach to discourse analysis, disrupting the hierarchy created from the macro- and micro-distinction in the policy process.

\section{Findings}

This section reports on the findings of this study in the attempt to address the research questions raised earlier in this article. In particular, the findings are presented in two parts, each corresponding to the language practice and language ideology aspects of Spolsky's [60] theory.

\footnotetext{
${ }^{5}$ Please refer to Appendix 1 for examples of the questions asked during the interview.

${ }^{6}$ Please refer to Appendix 2 for the notation system.
} 


\section{Language Practice: a "Trans-" Approach to Instruction}

As highlighted in the recent "trans-" turn in applied linguistics, the process of socializing into professional communication is often considered a multilingual and polysemiotic practice $[6,41]$. In this subsection, six instances of translingual practice are discussed with the support of retrospective comments collected from the interviews. The translanguaging moments were contextually motivated, serving different epistemological, pedagogical, and social purposes.

In the first two extracts, I draw attention to the impact of disciplinary differences on language choice and use through two classroom examples: one from the sciences and the other from the humanities. ${ }^{7}$ These examples were chosen as they represent the two extreme ends of the disciplinary spectrum, involving highly distinctive concepts of scholarship, values, and beliefs about teaching, learning, and research $[2,36,43]$. The first extract was taken from the course, Calculus. ${ }^{8}$

\section{Translingual Practice 1}

"Alright now, let me explain some basic properties of definitive integrals ((starts writing equations on the blackboard)). The first one. If you have your book, you can look at p. 414. There are some simple rules, but they are rules that you can expect. For example, if you have... sorry let me start with an easier one. If you have a constant function c. c is a real number. So suppose we've got a constant function c. Can anyone tell me what is the definitive integral, from a to $b$, when I'm integrating c? Just a constant function. What is this integral? Well, you can apply the fundamental theorem of calculus to find the anti-derivative $\mathrm{c}$, which is $\mathrm{c}(\mathrm{x})$, and then you do the formula. Or you can think about it geometrically. ((starts drawing a graph on the blackboard)) What is the picture for $\mathrm{y}=\mathrm{c}$ ? It's just a horizontal line. So what you are trying to find is...If this is $x=a$ and this is $x=b$, you are trying to find the area of a rectangle. What is the length of this rectangle? It's $c$. And what is the width? It's b minus a. What is the area? It will be c(b-a). It is quite straightforward."

As demonstrated in the extract above, abiding to the EMI policy in the math class was not difficult as the academic structures involved displayed a linear and repetitive pattern. Nonetheless, in spite of its "all English" appearance, the extract is an instance of translingual practice because there were other semiotic modes that played a central role in building and conveying knowledge. For example, the lecturer relied on numbers and graphs to complement her oral instruction, making visible how math is done. As noted by the lecturer, "Math is primarily expressed through equations. Even if the students do not comprehend what I am saying, they can still read the equations on the blackboard." This corresponds to what Canagarajah [6] described as "the embodied activity of boardwork" [p. 38].

\footnotetext{
${ }^{7}$ By sciences, I refer to the broader STEM category that includes science, technology, engineering, and mathematics; by humanities, I also take into consideration subjects in the arts and the social sciences.

${ }^{8}$ Please refer to Appendix 3 for the class profiles of the translingual practices.
} 
In the next extract, I present a different form of translanguaging from the course, Cross-Strait Relations. The focus of the class was on the development of the One China policy in the 1970s.

\section{Translingual Practice 2}

"There were some efforts where Taiwan tried to remain in the UN under the title of Taiwan. There were some discussions, some options or proposals to see if Taiwan and the PRC can be both in the UN, but Taiwan cannot reclaim to be the representative of China. Taiwan is Taiwan. But Chiang Kai-Shek always says the same thing. Do you remember the term? The royals will not compromise with whom? The traitors. 漢賊不兩立 [Shu Han and Cao Wei cannot coexist, or two enemies cannot live under the same sky]. Ok? It's a zero-sum game at that time with Chiang Kai-Shek. 毛澤東 [Mao Zedong] here and I'm out. I'm here then 毛澤 東 out. Because he can no longer sit with 毛澤東 anymore. He has been fooled. He has been manipulated by 毛澤東 for several times. So that's the reason why One China is very clear after that day."

In this extract, Chinese was an important medium for enhancing the understanding of cultural issues. Specifically, Chinese was employed not only to express certain names (e.g., 毛澤東), but also to highlight idioms and slangs (e.g., 漢賊不兩立). Different from the symbol-based discourse in the sciences, meaning-making activities in the humanities tend to have a higher linguistic density. Because of this, it is not unusual to see lecturers drawing on a variety of languages to convey and contextualize knowledge in situations where locality is emphasized.

Translingual practices were also common for other pedagogical reasons that may not necessarily be disciplinary specific. In other words, the translanguaging moments were not always driven by particular epistemological purposes, but to help support, expand, and enhance a deeper understanding of the subject matter $[1,19]$. A common example is the use of code-switching during instruction. As most of the classes were primarily attended by local Taiwanese students, many lecturers deliberately employed Chinese to help improve the students' comprehension. In the extract below, I show a snapshot of a lecture that centered on the teaching of Russian history in the fifteenth century.

\section{Translingual Practice 3}

"((reads and elaborates the notes on the PowerPoint slides) $)$ By the middle of the $15^{\text {th }}$ century, the once powerful Mongol empire had been reduced to a smattering...smattering...like a combination of many small khanates. Khanates 就是小汗國 [Khanates]. Khanates. Along the lower Volga. 在下游 [the lower course of the river]. Lower. 下游 [the lower course of the river]. Lower Volga. Volga river in Kazan. In Astrakhan and in Crimea. Crimea 就是克林米亞半島 [Crimea]. Ok. Only three big...or a little more important khanates were left at that time. And they were located in the lower Volga. In the lower Volga. 在伏爾加 河下游的三個汗國,就等著我們的伊凡三世來收拾它們 [The three Khanates in the lower Volga would eventually be conquered by Ivan III]" 
In this extract, Chinese was used for different purposes. First, words related to political entities and geographical locations (e.g., 小汗國 and 克林米亞半島) were translated as a way to connect the students' prior knowledge with what was newly taught. Second, Chinese was sometimes employed repetitively for the students to catch up with the lecturer's instruction (e.g., the reiteration of 下游). And third, quick Chinese summaries were made when important sections needed to be emphasized (e.g., the last sentence of the extract that marked a transition in history). Aside from the oral code-switching events, the lecturer also annotated specific vocabulary on the PowerPoint slides in Chinese. The reason for doing so is expressed below.

"When it comes to reading English, the most challenging thing for Taiwanese students is the amount of vocabulary to look up. You look up one word and there is another. Even if you look it up you might still not understand it. But with the translations and my explanations accompanied with some stories, they will be able to follow my instruction". (Dr. Yang)

The retrospective comment demonstrates the pedagogical validity of translanguaging. In addition to shifting in and out of Chinese and English, the lecturer moved back and forth between reading the slides and making oral extensions on certain parts. Similarly, the next extract shows how teaching was done through the creative use of different modalities. The extract presents a vignette of the course, Introduction to Machines.

\title{
Translingual Practice 4
}

\begin{abstract}
"Another one here is a common automaton. An automaton is very similar to a clock. Its function is only to make us happy. For amusement. Nothing for real industry. Only to show something funny. You can see it is from Japan. They call that a tea server. Maybe you can key in the words ((talks to the teaching assistant)), so the students will understand the operation of the tea server. Please turn to p. 38. ((looks at the list of videos on YouTube)) It's spoken in Japanese? Ok. Karakuri. This one. If you just key in Karakuri automaton. Yeah. This one, number four. ((the video starts playing)) I'll make the voice lower. ((turns down the volume)) So you can see the founder of this toy, the automaton. ((starts explaining how the automaton works by doing a voiceover in English))"
\end{abstract}

As indicated in the extract, instruction was supported with the use of textbooks and videos. However, as the video was in Japanese, it posed a dilemma on two levels. On the one hand, the majority of the students did not understand Japanese; on the other hand, the institutional policy mandates that all teaching materials in classes labeled as EMI should be in English. Due to these constraints, the lecturer decided to lower the volume of the video and give an oral explanation by himself. In this sense, teaching was mediated by both visual and audio means that were interdependent of each other. This phenomenon bears a similarity with what Blommaert [4] described as communicating with "truncated repertoires." In other words, as each person's linguistic knowledge is not necessarily complete and self-sufficient, it is not unusual to make use of different resources that are immediately available to achieve a certain end. 
A final aspect to highlight is the social side of translanguaging. By social, I refer to regulative and interpersonal types of classroom discourse that are not directly related to the teaching of content $[10,16]$. In the next extract, an example of translingual practice for managing classroom behavior is presented. The lecturer was teaching the concept of benefit-cost analysis to students in the class, Transportation Engineering.

\section{Translingual Practice 5}

"In this case, a life is worth 3 million dollars, but we don't really know if 3 million dollars is a reasonable number or not. But if we try to use BCA, we have to assign a monetary value to everything. Sometimes it doesn't make sense. Alright. We have to assign monetary value to human life, even to the worth of endangered species, clean air, noise pollution. It doesn't really make sense. ((long pause)) 你們兩個再講話就請你們到前面 [if you two continue to talk please come to the front] ((long pause)) And many BCA exclude information from the distribution of benefits and costs."

In this example, a warning was given to the students who were talking during the lecture. The long pauses and dynamic use of language created a contrastive effect, putting more weight to the lecturer's command. Specifically, Chinese was employed to demarcate different kinds of classroom discourse, signaling a switch from instructional to regulative talk. As expressed by the lecturer of this class, Chinese played an important role in getting the students' attention.

Additionally, translanguaging may also help enrich the affective climate of the classroom as a way to make the instruction more inclusive and welcoming. In the following extract taken from the course, Aircraft Analysis, the lecturer intentionally changed the medium of instruction to Taiwanese when he felt the students were struggling to concentrate.

\section{Translingual Practice 6}

L: "Alternatively, if the turbulence...the turbulence makes the aircraft slower. So move to say...b1". b1" is slower than b1. So your power required now becomes smaller than the power available. So you have excess power. Excess power. This excess power is going to increase your air speed. 對不對 [yes or no]?

Ss: 對 $[\text { yes }]^{\circ}$

L: 對 [yes $]^{\circ}$ Thank you.”

This brief comprehension check occurred after the lecturer presented a lengthy explanation on the topic of climbing flights. Although there were other short moments of interaction throughout the class, the students became less responsive as the lecture proceeded into the second hour. To keep the students focused, a different language was adopted. As highlighted by the lecturer:

"I use Chinese or Taiwanese just to tease the students. It's suppose to be a joke. I won't keep using other languages because eventually I have to teach in English. 
Occasionally Chinese or Taiwanese will emerge in the middle of my instruction just to create a particular effect." (Dr. Gu)

The retrospective comment shows that the use of Taiwanese was a way to interact with the students on a more personal level. However, in most of the classes observed, Taiwanese was employed very minimally, and often reserved to interpersonal classroom discourse.

\title{
Language Ideology: the Dominance of Monolingual Discourses
}

While the number of translingual instances are not limited to the examples above, translanguaging spaces in the higher education classroom were constrained by a number of explicit and implicit ideological forces. In particular, the institutional policy and discourses of internationalization were the most frequently invoked themes in the lecturers' interpretations of EMI. The discursive effects of the institutional policy are indicated in the interview extracts below. The juxtaposition of the extracts draws attention to the similarity of the lecturers' responses.

\begin{abstract}
"The university mandates that everything has to be in English, including the syllabus, exam papers, and assignments. Even the question and answer sessions during break time have to be in English. Many students are not aware of this. They speak to me in Chinese during break time, but I immediately respond in English. They get why I do this. It is the policy." (Dr. Kuo)

"I am not supposed to use Chinese. This is the university's policy. We need to implement it. I tell the students at the beginning that speaking Chinese is not allowed. No matter what your nationality is, you have to use English.” (Dr. Chen)
\end{abstract}

The two examples of "scale-jumping" point towards certain expectations on a higher scale level that views English as an idealized and homogenized entity. By labeling certain courses as English instructed, artificial linguistic boundaries are created to compartmentalize language into separate spaces. As social institutions are often sites of ideological production, this reflects diffused ways of language management in defining reality, regulating behavior, and allocating resources accordingly [39, 47, 51]. The outcome of such policy discourse can be observed in the following classroom scenario.

\section{Translingual Practice 7}

"Ok. Now I show you the Chinese four religions, but actually they are Taiwanese statues, or deity. This one is very popular. The god of earth. The god of land. Taiwanese students call that 土地公 [the god of earth]. Actually I'm not allowed to use Mandarin. Just to help you understand the material. It's very interesting, the deity." 
In this example taken from the course, Religion and Society, an instance of translanguaging emerged when the lecturer expressed "the god of earth" in Chinese. The translingal practice was followed by a reference to the institutional policy ("Actually I'm not allowed to use Mandarin"), and then a line of justification to explain the reason why Chinese was used, ("Just to help you understand the material"). Although the extract demonstrates the lecturer's capacity to appropriate the "English only" definition of EMI, it also unveils the political dimensions of ideological control that permeate the policy process.

Aside from the monolingual effects that are directly (perhaps unintentionally) enhanced through the institutional policy, discourses of internationalization play an important role in furthering the desire to adopt English as the medium of instruction. Again, I offer two juxtaposed quotes to illustrate this.

"Internationalization is one of our university's core development goals. Because of this emphasis, we have a lot of international students. To promote internationalization, we also need a set of supplementary measures, like providing EMI courses. Otherwise the international students won't be able to understand what we're teaching." (Dr. Lin)

"When we talk about internationalization, EMI is usually considered an indicator that is easy to assess. Everything is about indicators. For example, how can we internationalize a university? How many international students do we have? How many international universities are we collaborating with? How many EMI courses do we offer?" (Dr. Su)

As expressed in the extracts, the promotion of EMI is inextricably linked to the rhetoric of internationalization in tertiary education. By internationalization, this usually refers to the commercial strategy adopted by higher education institutions to alleviate problems caused by declining birth rates in Taiwan. In other words, as many universities are facing the stark reality of shrinking enrolments, recruiting international students has become an alternative source of financial input in the competition for survival [62]. While the changing demographics of higher education means that more linguistic resources are brought into the classroom, the process of teaching and learning does not necessarily become more multilingual. As English is widely perceived as a form of capital that can be invested, converted, and exchanged in the global field, it tends to be adopted as the primary medium of instruction, furthering the depth of English penetration. In this sense, the emphasis on internationalization is often complicit in creating a hierarchy of languages, naturalizing the indispensable role of English in teaching, learning, and research.

\section{Discussion}

To explore how translanguaging spaces may be enabled or constrained in the policy process, the findings of this study draw attention to the underlying tensions that exist between translingual practices and monolingual ideologies in the higher education 
classroom. On the one hand, the lecturers recognized the importance of translanguaging to construct and communicate knowledge. On the other hand, they tried to follow the English-only requirement as closely as possible, deliberately avoiding the excessive use of other languages during instruction. While translanguaging as practice was not considered unusual, translanguaging as ideology was less so.

As presented in this study, the translingual practices in the higher education classroom played a vital role in attaining a range of epistemological, pedagogical, and social goals. By fluidly crossing linguistic and communicative borders [6, 41], the lecturers used different languages (e.g., English, Chinese, and Taiwanese), modalities (e.g., PowerPoint slide, videos, and textbooks), and semiotic resources (e.g., numbers) in the process of teaching and learning. However, different from the discussions of translanguaging in primary or secondary school settings [12, 23, 49], translingual practices in university contexts are deeply embedded in wider sociopolitical discourses related to the spread of English. As English often implies human capital development, modernization, and integration into the global economy [15, 31, 33], there is a strong desire to enhance the use of English as the language of instruction, but not translanguaging spaces. As highlighted by Pennycook [52], it is not English that is the problem, but the discourses around it that create the many distorted projections of language, education, and the world.

While the increasing status of English in academia may seem inevitable, in this study I argue for the need to introduce a more inclusive model as a response to the changing linguistic realities of higher education $[42,46,50]$. In particular, I suggest that the concept of translanguaging be recognized, if not adopted, across different levels of the policy process. As highlighted in the title of this study, to move beyond the English box ${ }^{9}$ carries several implications. First, it means to recognize the diverse linguistic profiles that are unique to each classroom setting (to become multilingual); and second, it calls for a more dynamic and fluid use of meaning-making resources in the process of constructing and communicating knowledge (to become translingual). To inform policy-making and practice, questions that should be asked include: how do we tap into students' and lecturers' entire linguistic repertoires? What are the available and appropriate mediums to bring out specific knowledge in each discipline? How can EMI be redefined? Instead of determining the language of instruction a priori, it may be more important to focus on ways to become more linguistically aware and ecologically oriented, acknowledging translanguaging as situated, holistic, and embodied activities that emerge from the interactions between people, artifacts, and space $[6,46,53]$.

\section{Conclusion}

In response to the call for reconceptualizing the "E" in EMI $[13,32]$, in this study I have taken a "trans-" approach to examine the process of constructing and communicating knowledge. Specifically, I have combined the "trans-" approach with Spolsky's [60] theory of language policy to explore how translanguaging spaces are enabled and constrained in the higher education classroom. The findings show

\footnotetext{
${ }^{9}$ The box metaphor was inspired by Makalela's [44] research on the effects of translanguaging strategies for multilingual classrooms.
} 
that translingual practices were important for a range of educational purposes, but at the same time significantly influenced by monolingual ideologies that permeate the policy process. By studying policy from the bottom-up, I propose to move current EMI policies from an English-only focus toward multilingual and translingual awareness.

As noted by Li [41], taking a "trans-" approach to pedagogy "empowers both the learner and the teacher, transforms the power relations, and focuses the process of teaching and learning on making meaning, enhancing experience, and developing identity" [p. 15]. Nonetheless, to adopt a "trans-" perspective does not mean to advertise plurality for the sake of plurality, but to ensure that every pedagogical decision made is contextually well-motivated [37]. This involves the use of different languages, modes, and semiotic resources according to the specific goals and demands in each classroom setting. In other words, the "trans-" term should be handled with care and responsibility.

While there are a number of translanguaging instances discussed in this article, this study has only marked the beginning of more research to be done to open up translingual spaces in the higher education setting. In particular, more ethnographic data with other policy actors will be needed to investigate how monolingual discourses may be critically transformed. By examining the interactions between different scales of the policy process, it is hoped that the "trans-" approach may ultimately illuminate ways to improve language policy-making and practice in higher education in the future.

\section{Compliance with Ethical Standards}

Conflict of Interest The author declares that there is no conflict of interest.

\section{Appendix 1. Examples of the interview questions}

Part 1:

1.1 What is the role of English/Chinese/other languages in your instruction?

1.2 What other semiotic resources and modalities are central to the construction and communication of knowledge in your discipline?

\section{Part 2:}

2.1 What motivated you to teach in English/offer EMI courses?

2.2 How do you think of the overall EMI movement in your university and in Taiwan? 


\section{Appendix 2}

Table 1 Notation system for transcription

\begin{tabular}{ll}
\hline yes, & A comma indicates continuing intonation \\
$?$ & Rising intonation, not necessarily a question \\
end. & A full stop indicates falling (stopping) intonation \\
$(($ wave hands $))$ & Researcher's comments on non-verbal actions \\
$\ldots$ & Three dots indicate a pause of about $1 \mathrm{~s}$ \\
foo- & An abrupt cut-off of the prior word or sound \\
[translation] & Indicates translated text \\
\hline
\end{tabular}

\section{Appendix 3}

Table 2 Class profile of translingual practice 1-7

\begin{tabular}{llll}
\hline $\begin{array}{l}\text { Translingual } \\
\text { practice }\end{array}$ & Class & $\begin{array}{l}\text { Lecturer's disciplinary } \\
\text { background }\end{array}$ & Student population of the class \\
\hline 1. & Calculus & Math & 100 (30 int'l) \\
2. & Cross-Strait Relations & Politics & $100(50$ int'l) \\
3. & Russian History & International relations & $90(5$ int'l) \\
4. & Introduction to Machines & Mechanical engineering & $80(30$ int'l) \\
5. & Transportation Engineering & Transportation engineering & $26(3$ int'l) \\
6. & Aircraft Analysis & Aerospace engineering & $20(2$ int'l) \\
7. & Religion and Society & Sociology & $70(35$ int'l) \\
\hline
\end{tabular}

Open Access This article is distributed under the terms of the Creative Commons Attribution 4.0 International License (http://creativecommons.org/licenses/by/4.0/), which permits unrestricted use, distribution, and reproduction in any medium, provided you give appropriate credit to the original author(s) and the source, provide a link to the Creative Commons license, and indicate if changes were made.

\section{References}

1. Baker, C. (2001). Foundations of bilingual education and bilingualism (3rd ed.). Clevedon: Multilingual Matters.

2. Becher, T. (2001). Academic tribes and territories: intellectual enquiry and the culture of disciplines (2nd ed.). Philadelphia: SRHE \& Open University Press.

3. Blommaert, J. (2007). Sociolinguistic scales. Intercultural Pragmatics, 4(1), 1-19.

4. Blommaert, J. (2010). The sociolinguistics of globalization. Cambridge: Cambridge University Press.

5. Canagarajah, S. (2012). Translanguaging in the classroom: emerging issues for research and pedagogy. Applied Linguistics Review, 2, 1-28.

6. Canagarajah, S. (2018). Translingual practice as spatial repertoires: expanding the paradigm beyond structuralist orientations. Applied Linguistics, 39(1), 31-54. 
7. Canagarajah, S., \& De Costa, P. I. (2016). Introduction: scales analysis, and its uses and prospects in educational linguistics. Linguistics and Education, 34, 1-10.

8. Chang, Y. Y. (2010). English-medium instruction for subject courses in tertiary education: reactions from Taiwanese undergraduate students. Taiwan International ESP Journal, 2(1), 55-84.

9. Chen, S., \& Tsai, Y. (2012). Research on English teaching and learning: Taiwan (2004-2009). Language Teaching, 45(02), 180-201.

10. Christie, F. (2002). Classroom discourse analysis: a functional perspective. London: Bloomsbury Publishing.

11. Chung, C. L, \& Lo, M. L. (2016). Prospect and case study of English-medium instruction of transportation courses in Taiwanese universities. English Teaching \& Learning, 40(3), 87-121.

12. Creese, A., \& Blackledge, A. (2010). Translanguaging in the bilingual classroom: a pedagogy for learning and teaching? The Modern Language Journal, 94(1), 103-115.

13. Dafouz, E., \& Smit, U. (2016). Towards a dynamic conceptual framework for English-medium education in multilingual university settings. Applied Linguistics, 37(3), 397-415.

14. Dearden, J. (2014). English as a medium of instruction-a growing global phenomenon. London: British Council.

15. Fenton-Smith, B., Humphreys, P., \& Walkinshaw, I. (Eds.). (2017). English medium instruction in higher education in Asia-Pacific: from policy to pedagogy (Vol. 21). Dordrecht: Springer.

16. Ferguson, G. (2003). Classroom code-switching in post-colonial contexts: functions, attitudes and policies. AILA Review, 16(1), 38-51.

17. Ferguson, G. (2006). Language planning and education. Scotland: Edinburgh University Press.

18. Galloway, N., Kriukow, J., \& Numajiri, T. (2017). Internationalisation, higher education and the growing demand for English: an investigation into the English medium of instruction (EMI) movement in China and Japan. London: British Council.

19. Garcia, O., \& Wei, L. (2014). Translanguaging: language, bilingualism and education. New York: Palgrave Macmillan.

20. Hamid, M. O., Nguyen, H. T. M., \& Baldauf Jr., R. B. (2013). Medium of instruction in Asia: context, processes and outcomes. Current Issues in Language Planning, 14(1), 1-15.

21. Hawkins, M. R., \& Mori, J. (2018). Considering 'trans-'perspectives in language theories and practices. Applied Linguistics, 39(1), 1-8.

22. Hornberger, N. H., \& Johnson, D. C. (2007). Slicing the onion ethnographically: layers and spaces in multilingual language education policy and practice. TESOL Quarterly, 41(3), 509-532.

23. Hornberger, N. H., \& Link, H. (2012). Translanguaging and transnational literacies in multilingual classrooms: a biliteracy lens. International Journal of Bilingual Education and Bilingualism, 15(3), 261-278.

24. Huang, D. F. (2013). Aspects of English medium instruction research: retrospect and prospect. In D. F. Huang, M. Singh, \& C.J. Tseng (Eds). Research perspectives on English medium instruction in the globalized higher education (pp. 35-70). Taiwan: Southern Taiwan University of Science \& Technology.

25. Hult, F. M. (2010). Analysis of language policy discourses across the scales of space and time. International Journal of the Sociology of Language, 202, 7-24.

26. Hult, F. M., \& Johnson, D. C. (2015). Research methods in language policy and planning: a practical guide. Oxford: Wiley.

27. Hymes, D. (2001). Foundations in sociolinguistics: an ethnographic approach. Philadelphia: University of Pennsylvania Press.

28. Johnson, D. C. (2011). Critical discourse analysis and the ethnography of language policy. Critical Discourse Studies, 8(4), 267-279.

29. Johnson, D. C. (2013). Language policy. New York: Palgrave Macmillan.

30. Källkvist, M., \& Hult, F. M. (2016). Discursive mechanisms and human agency in language policy formation: negotiating bilingualism and parallel language use at a Swedish university. International Journal of Bilingual Education and Bilingualism, 19(1), 1-17.

31. Kedzierski, M. (2016). English as a medium of instruction in East Asia's higher education sector: a critical realist Cultural Political Economy analysis of underlying logics. Comparative Education, 52(3), 375-391.

32. Kirkpatrick, A. (2014). The language (s) of HE: EMI and/or ELF and/or multilingualism? The Asian Journal of Applied Linguistics, 1(1), 4-15.

33. Kirkpatrick, A., \& Liddicoat, A. J. (2017). Language education policy and practice in East and Southeast Asia. Language Teaching, 50(2), 155-188.

34. Kress, G. (2009). Multimodality: a social semiotic approach to contemporary communication. London: Routledge.

35. Kroskrity, P. V. (2008). Language ideologies. In A. Duranti (Eds). A companion to linguistic anthropology (pp. 496-517). Cornwall: John Wiley \& Sons. 
36. Kuteeva, M., \& Airey, J. (2014). Disciplinary differences in the use of English in higher education: reflections on recent language policy developments. Higher Education, 67(5), 533-549.

37. Lee, J. W. (2017). The politics of translingualism: After englishes. Routledge. Logan: Utah State University Press.

38. Levinson, B. A. \& Sutton, M. (2001). Policy as practice: toward a comparative sociocultural analysis of educational policy (Vol. 1). Westport: Greenwood Publishing Group.

39. Levinson, B. A., Sutton, M., \& Winstead, T. (2009). Education policy as a practice of power: theoretical tools, ethnographic methods, democratic options. Educational Policy, 23(6), 767-795.

40. Li, W. (2010). Moment analysis and translanguaging space: discursive construction of identities by multilingual Chinese youth in Britain. Journal of Pragmatics, 43(5), 1222-1235.

41. Li, W. (2018). Translanguaging as a practical theory of language. Applied Linguistics, 39(1), 9-30.

42. Liddicoat. (2016). Language planning in universities: teaching, research and administration. Current Issues in Language Planning, 17(3-4), 231-241.

43. Lueddeke, G. R. (2003). Professionalising teaching practice in higher education: a study of disciplinary variation and 'teaching scholarship'. Studies in Higher Education, 28(2), 213-228.

44. Makalela, L. (2015). Moving out of linguistic boxes: the effects of translanguaging strategies for multilingual classrooms. Language and Education, 29(3), 200-217.

45. Martin-Jones, M. (2015). Classroom discourse analysis as a lens on language-in-education policy processes. In N. Markee (Ed.), The handbook of classroom discourse and interaction (pp. 94-106). Oxford: Wiley.

46. Mazak, C. M., \& Carroll, K. S. (Eds.). (2017). Translanguaging in higher education. Bristol: Multilingual Matters.

47. Milroy, J. (2001). Language ideologies and the consequences of standardization. Journal of SocioLinguistics, 5(4), 530-555.

48. Otheguy, R., García, O., \& Reid, W. (2015). Clarifying translanguaging and deconstructing named languages: a perspective from linguistics. Applied Linguistics Review, 6(3), 281-307.

49. Palmer, D. K., Martínez, R. A., Mateus, S. G., \& Henderson, K. (2014). Reframing the debate on language separation: toward a vision for translanguaging pedagogies in the dual language classroom. The Modern Language Journal, 98(3), 757-772.

50. Paulsrud, B., Rosén, Straszer, J. B., \& Wedin, Å. (2017). New perspectives on translanguaging and education. Bristol: Multilingual Matters.

51. Pennycook, A. (2006). Postmodernism in language policy. In T. Ricento (Ed.), An introduction to language policy: theory and method (pp. 60-76). Oxford: Wiley.

52. Pennycook, A. (2012). Afterword: could Heracles have gone about things differently. In V. Rapatahana \& P. Bunce (Eds.), English language as hydra: its impacts on non-English language cultures (pp. 255262). Bristol: Multilingual Matters.

53. Pennycook, A. (2016). Posthumanist applied linguistics. London: Routledge.

54. Ricento, T. (2000). Historical and theoretical perspectives in language policy and planning. Journal of SocioLinguistics, 4(2), 196-213.

55. Rose, H., \& McKinley, J. (2018). Japan's English-medium instruction initiatives and the globalization of higher education. Higher Education, 75(1), 111-129.

56. Scollon, R., \& Scollon, S. W. (2007). Nexus analysis: refocusing ethnography on action. Journal of SocioLinguistics, 11(5), 608-625.

57. Seidman, I. (2006). Interviewing as qualitative research: a guide for researchers in education and the social sciences. New York: Teachers college press.

58. Shohamy, E. G. (2006). Language policy: hidden agendas and new approaches. London: Routledge.

59. Silver, R. E., \& Steele, R. S. (2004). Priorities in English language education policy and classroom implementation. Language Policy, 4(1), 107-128.

60. Spolsky, B. (2004). Language policy. Cambridge, UK: Cambridge University Press.

61. Tollefson, J. W., \& Tsui, A. B. (Eds.). (2003). Medium of instruction policies: which agenda? Whose agenda? London: Routledge.

62. Tsou, W., \& Kao, S. M. (Eds.). (2017). English as a medium of instruction in higher education: implementations and classroom practices in Taiwan (Vol. 8). Singapore: Springer.

63. Woolard, K. A. (1992). Language ideology: issues and approaches. Pragmatics, 2(3), 235-249.

64. Wu, W. S. (2006). Students' attitudes toward EMI: Using Chung Hua University as an example. Journal of Education and Foreign Language and Literature, 4, 67-84.

65. Yeh, C. C. (2012). Instructors' perspectives on English-medium instruction in Taiwanese universities. Curriculum Instruction Quarterly, 16(1), 209-232. 